Kastamonu Eğitim Dergisi
$\begin{aligned} & \text { Kastamonu Education Journal } \\ & \text { Ocak 2020 Cilt:28 Sayı:1 } \\ & \text { kefdergi.kastamonu.edu.tr }\end{aligned}$

\title{
Sosyal Bilgiler Öğretmen Adaylarının Mesleki Özyeterliklerine İlişkin Algılarının İncelenmesi 1
}

\author{
Examining the Perceptions of Social Studies Prospective Teachers' \\ Sense of Efficacy \\ Serpil RECEPOĞLU², Bilgin Ünal ỉBRET ${ }^{3}$
}

Öz

$\mathrm{Bu}$ araştırmanın amacı, Sosyal Bilgiler öğretmen adaylarının mesleki özyeterliklerine ilişkin algılarını ortaya koymaktır. Bu amaç doğrultusunda, araştırmanın çalışma grubunu 12 üniversitede Eğitim Fakültelerinin 2014-2015 öğretim yılında illköğretim Sosyal Bilgiler öğretmenliği 1.2.3.4. sınıflarında okuyan 2193 öğretmen adayı oluşturmaktadır. Araştırma tarama modelinde betimsel bir araştırmadır. Araştırmadan elde edilen sonuçlara göre, genel olarak Sosyal Bilgiler öğretmen adaylarının özyeterlik algıları incelendiğinde "oldukça yeterli" düzeyde olduğu bulunmuştur. Sosyal Bilgiler öğretmen adaylarının özyeterlik algıları öğretmen adaylarının cinsiyetine göre anlamlı bir farklılık göstermemektedir. Bununla birlikte, Sosyal Bilgiler öğretmen adaylarının özyeterlik algıları sınıf düzeyine göre anlamlı bir şekilde değişmektedir. Sosyal Bilgiler öğretmen adaylarının özyeterlik algıları 1. sınıfta en yüksek düzeyde; 4. sınıfta ise en düşük düzeydedir. Sosyal Bilgiler öğretmen adaylarının özyeterlik algılarının üniversite değişkenine göre anlamlı farklıık göstermektedir.

Anahtar Kelimeler: Sosyal bilgiler, sosyal bilgiler öğretmen adayı, öğretmen özyeterliği.

\section{Abstract}

The aim of this study is to examine the perceptions of social studies prospective teachers' sense of efficacy. This is a descriptive research in survey model. The participants of the study are 2193 social studies prospective teachers of 1th 2nd 3th 4th grade at Faculty of Education of 12 Universities in the 2014-2015 academic years. As a result of the research, In general, it has been determined that socıal studies prospective teachers' sense of efficacy perceptions are "quite sufficient". socıal studıes prospective teachers' sense of efficacy perception does not show a significant difference according to the gender. Social studies prospective teachers' sense of efficacy vary significantly according to grade level. social studies prospective teachers' sense of efficacy are at the highest level in the first grade, but it is the lowest level in the 4 th grade. Social studies prospective techers' self-efficacy perceptions differ significantly according to university

Keywords: Social studies, social studies prospective teachers, teachers' sense of efficacy

\footnotetext{
${ }^{1}$ International Conference on Quality in Higher Education 2018'de bildiri olarak sunulan bu makale, Kastamonu Üniversitesi Sosyal Bilimler Enstitüsünde Prof. Dr. B. Ünal IBRET’ in danışmanlı̆̆ında Serpil RECEPOĞLU tarafından yazıımış olan tezden üretilmiştir.

${ }^{2}$ Kastamonu Üniversitesi, Eğitim Fakültesi, Eğitim Bilimleri Bölümü, Kastamonu, Türkiye, http://orcid.org/0000-0002-4189-4456, melekrecepoglu@gmail.com 3 Kastamonu Üniversitesi, Eğitim Fakültesi, Sosyal Bilgiler Öğretmenliği Bölümü, Kastamonu, Türkiye, http://orcid.org/0000-0001-9105-7595 bibret@kastamonu.edu.tr
} 


\section{Extended Abstract}

Purpose: The aim of this study is to examine the perceptions of social studies prospective teachers' sense of efficacy. The main aim of the education is to grow individuals who are beneficial, productive and scientific for society and country. The most important task in the education of individuals with these characteristics belongs to teachers. Today, the teaching profession, is a field that requires special expertise in the field of knowledge and skills and professional competence with social, cultural, economic, scientific and technological dimensions related to education (Şişman and Acat, 2003). Self-efficacy beliefs, which have an important place in the success of individuals, are also important for teachers. Self-efficacy is one of the key concepts emphasized in Bandura's Social Learning Theory (Bandura, 1977). Bandura defines the concept of self-efficacy as an effective feature in the occurrence of behaviors and its self-judgment on the capacity of the individual to organize and perform the necessary activities to show a certain performance (Bandura, 1997). In other words, it is the assessment of a man's capacity to make his own achievements (Viau, 2015, p. 31). The individual's belief in the future about what to do in certain situations (Woolfolk Hoy, 1990). Teacher self-efficacy is defined as the perceptions of teachers about their capacity to influence students' performances or how much they can show their behaviors to perform their tasks successfully (Ashton, 1984). Teachers direct the learning-teaching process personally and affect the student's academic and social development, so that the teachers who influence the society are directly proportional to their success in the areas of high self-efficacy perception.

Method: This is a descriptive research in survey model. The participants of the study are 2193 social studies prospective teachers of 1th 2nd 3th 4th grade at Faculty of Education in Kastamonu University, Marmara University, Trakya University, Pamukkale University, Gazi University, Abant İzzet Baysal University, Mehmet Akif Ersoy University, Ahi Evran University, Kastamonu University, Karadeniz Teknik University, Fırat University, Erzincan University, Adıyaman University in the 2014-2015 academic years. In this research "Teachers' sense of efficacy scale" developed by Tschannen-Moran and Hoy (2001) was used as a means of data collection, and the Turkish adaptation, validity and reliability study was conducted by Çapa, Çakıroğlu and Sarıkaya (2005). Teachers' sense of efficacy scale consists of 24 items and three sub-dimensions. The data obtained from the study participants were analyzed using SPSS 16.0 statistical software package. Frequency and percentage analysis mean and standard deviation values were used in data analysis. The differences of between perceptions were analyzed by $t$ test and one way anova.

Findings: As a result of the research, In general, it has been determined that socıal studies prospective teachers' sense of efficacy perceptions are "quite sufficient". Social studies prospective teachers' sense of efficacy vary significantly according to grade level. social studies prospective teachers' sense of efficacy are at the highest level in the first grade, but it is the lowest level in the 4th grade. The perceptions of social studies prospective teachers' sense of efficacy do not show a significant difference according to the gender. The perceptions of social studies prospective teachers' sense of efficacy vary significantly according to universities.

Conclusion: In the research, social studies prospective teachers' sense of efficacy perceptions have been high and it has been determined that the high level of self-efficacy perceptions of social studies prospective teachers can contribute to to higher motivation and more successful in teaching profession. 


\section{Giriş}

Eğitim, bireyin tüm nitelikleriyle gelişmesini, toplum için verimli ve üretken olmasını, yaşamı sorgulayabilen, bilimsel düşünebilen bireyler yetiştirmeyi amaçlamaktadır. Öğretmenler bu özellikleri taşıyan bireylerin yetiştirilmesinde en önemli göreve sahiptir. Zamanımızda öğretmenlik mesleği, eğitim ile alakalı sosyal, kültürel, ekonomik, bilimsel ve teknolojik alanlar ile uzmanlık bilgi ve becerisine sahip olan ve meslekte yeterlilik isteyen bir alandır. Bireylerin başarılarında önemli bir yeri olan özyeterlik inançlarının öğretmenler açısından da önemlidir. Özyeterlik; ilk kez Bandura'nın Sosyal Öğrenme Kuramı'nda (Sosyal Bilişsel Kuram) üzerinde durulan temel kavramlardandır (Bandura, 1986). Bandura özyeterlik kavramını, davranışların meydana gelmesinde etkin bir özellik ve "bireyin, belli bir performansı göstermek için gerekli etkinlikleri organize edip, başarılı olarak yapma kapasitesi hakkında kendine ilişkin yargısı" şeklinde tanımlanır (Bandura, 1977). Başka bir tanımda ise, bireyin belli durumlarda ne yapabileceğine dair geleceğe ilişkin inancıdır (Woolfolk Hoy, 1990). Öğretmen özyeterliği, Tschannen-Moran ve Woolfolk-Hoy (2001) ise bir öğretmenin, öğrenci katılımı ve öğrenmeye ilişkin arzulanan sonuçları gerçekleştirme kapasitesine olan inancı olarak ifade etmektedir. Öğretmenler öğrenme öğretme sürecini bizzat yönlendirir ve öğrencinin akademik ve sosyal yönden gelişimlerine etki eder. Dolayısıyla topluma etki eden öğretmenlerin özyeterlik algılarının yüksek olması alanlarında başarıı olmalarıyla doğru orantılıdır. Özyeterlik algısı yüksek olan öğretmenler; farklı fikirlere açık, farklı öğretim yöntemlerini kullanmaya hevesli, hata yapan öğrencilere karşı daha anlayışlı, öğretmede hevesli, öğrenci ihtiyaçlarına gören, sıcak öğrenme ortamı oluşturabilen, öğrencilerin öğrenme güçlükleri karşısında daha dayanıklı, öğrenci odaklı ders işleyen kişilerdir (Tschannen-Moran ve Hoy, 2001, s. 783784; Henson, 2001, s. 5). Özyeterlik algısı düşük olan öğretmenler ise; öğrenci motivasyonuna yönelik olumsuz görüşlere sahip, katı sınıf kurallarına bağı, cezalandıran, öğretmen odaklı ders işleyen kişilerdir (Tschannen-Moran, Woolfolk-Hoy ve Hoy, 1998, s. 235; Henson, 2001).

Öğretmen yeterliği üzerine yabancı alan yazında yapılan araştırmalar mevcuttur (Gibson ve Dembo, 1984; Enochs ve Riggs, 1990; Moore ve Esselman, 1992: Soodak ve Podel, 1993; Guskey ve Passaro, 1994; Allinder, 1995; Cannon ve Scharmann, 1996; Goddart, Hoy ve Woolfolk Hoy, 2000; Tschannen-Moran ve Hoy, 2001; Milner ve Woolfolk Hoy, 2002; Caprara, Barbaranelli, Steca ve Malone, 2006;). Yerli alan yazında, öğretmen adaylarının özyeterlikleri ile ilgili çeşitli araştırmalar mevcuttur (Çoban ve Sanalan, 2002; Akkoyunlu ve Kurbanoğlu, 2003; Akkoyunlu ve Orhan, 2003; Can, Günhan ve Erdal, 2005; Aşkar ve Umay, 2001; Celep, 2000; Çapri ve Çelikkaleli, 2008; Savran ve Çakıroğlu, 2001; Kurbanoğlu ve Akkoyunlu, 2002; Morgil, Seçken ve Yücel, 2004; Özdemir, 2008; Özenoğlu Kiremit, 2006; Usluel, 2006; Akkuzu ve Akçay, 2012; Akbaş ve Çelikkaleli, 2006; Akbulut, 2006; Altunçekiç, Yaman ve Koray,2005; Ekinci, Yıldırım, Bindak, Öter, Özdaş ve Akın, 2014; Çakıroğlu, Çakıroğlu ve Boone, 2005; Demirtaş, Cömert ve Özer, 2009; Ekici, 2008; Coşgun ve İlgar, 2004; Gerçek, Yılmaz, Köseoğlu ve Soran, 2006; Güven ve Ersin, 2007; Karadeniz ve Özdemir, 2006; Küçükyılmaz ve Duban, 2006; Yüksel, 2014; Zayimoğlu-Öztürk, 2013; Mutlu Bozkurt, 2013; Uslu, 2014; Tatlı Dalioğlu; 2016) araştırmalara rastlanmaktadır.

Eğitim ve öğretimde önemli bir yeri olan özyeterlik ile ilgili çalışmaların önemi giderek artmaktadır. Öğrenme öğretme sürecini yönlendirecek olan öğretmen adaylarının özyeterlik algılarının yüksek olması, akademik başarı, motivasyon, zaman yönetimi konusunda başarılı olmalarında etkili olabilir. Bu araştırmanın amacı, Sosyal Bilgiler öğretmen adaylarının mesleki özyeterliklerine ilişkin algılarını ortaya koymaktır. Bu amaçla, Sosyal Bilgiler öğretmen adaylarının mesleki özyeterliklerine ilişkin algılarının cinsiyete, sınıf düzeyine göre ve üniversiteye göre değişiklik gösterip göstermediği de incelenmiştir. Bu doğrultuda şu sorulara cevap aranmıştır.

1. Sosyal Bilgiler öğretmen adaylarının mesleki özyeterliklerine ilişkin algıları ne düzeydedir?

2. Sosyal Bilgiler öğretmen adaylarının mesleki özyeterliklerine ilişkin algıları cinsiyete göre farkılışmakta mıdır?

3. Sosyal Bilgiler öğretmen adaylarının mesleki özyeterliklerine ilişkin algıları sınıf düzeyine göre farklılaşmakta mıdır?

4. Sosyal Bilgiler öğretmen adaylarının mesleki özyeterliklerine ilişkin algıları öğrenim gördükleri üniversiteye göre farklılaşmakta mıdır? 


\section{Yöntem}

Araştırmanın bu kısmında, araştırmanın modeli, çalışma grubu, veri toplama araç ve teknikleri, verilerin toplanması ve analizi ile ilgili bilgiler açıklanmıştır.

\section{Araştırmanın Modeli}

Bu araştırma tarama modelinde betimsel nitelikte bir araştırmadır. Tarama modelleri, geçmişte veya şuan var olan bir durumu var olduğu biçimiyle betimlemeyi amaçlayan araştırmalara uygun bir modeldir (Karasar, 2009). Bu araştırmada sosyal bilgiler öğretmen adaylarının mesleki özyeterliklerine ilişkin algılarının ne olduğunu ortaya koymak amaçlandığı için betimsel araştırma modeli seçilmiştir.

\section{Araştırmanın Çalışma Grubu}

Araştırmanın çalışma grubunu 2014-2015 öğretim yılında 12 üniversitede Eğitim Fakültelerinin Illköğretim Sosyal Bilgiler öğretmenliği 1.2.3.4. sınıflarında öğrenim gören 2193 öğretmen adayı oluşturmaktadır Buna göre araştırma Türkiye'de NUTS 1(Nomenclature of Territorial Units for Statistics), düzeyinde belirlenen ilköğretim Sosyal Bilgiler Öğretimi Anabilim Dalı 1.2.3.4. sını öğrencilerinin bulunduğu Marmara, Trakya, Pamukkale, Gazi, Abant İzzet Baysal, Mehmet Akif Ersoy, Ahi Evran, Kastamonu, Karadeniz Teknik, Fırat, Erzincan, Adıyaman Üniversiteleri'nde gerçekleştirilmiştir. NUTS 1 (Nomenclature of Territorial Units for Statistics), Avrupa Birliği tarafından kabul edilen istatistiki bölge birimlerine verilen genel bir ad olarak bilinmektedir. NUTS 1 üzerinden yürütülen örnekleme belirleme aşamasında, araştırmadaki il seçimini NUTS 1'i oluşturan 12 bölge içerisinden ulaşılabilirlik, ekonomiklik, uygulama kolaylığı gibi ölçütler dikkate alınarak her bölgeden 1 il ve 1 üniversite seçilmiş, seçilen her üniversitenin eğitim fakültesinde okuyan sosyal bilgiler öğretmen adaylarının tamamı örneklem grubuna dahil edilmiştir. Araştırmaya katılan 2193 sosyal bilgiler öğretmen adayının 1202'si kadın (\% 54.8), 991 i (\%45.2) erkektir. Sosyal bilgiler öğretmen adayının 543'ü 1.sınıf (\%24.8), 589'u 2.sınıf (\%26.9), 556'sı 3.sınıf (\%25.4), 505'i (\%23.0) 4.sınıftır. Sosyal bilgiler öğretmen adayının 215'i (\% 9.8), Kastamonu Üniversitesi, 189’u (\%8.6) Karadeniz Teknik Üniversitesi, 167'si (\%7.6) Mehmet Akif Ersoy Üniversitesi, 128'i (\%5.8) Marmara Üniversitesi, 219'u (\%10.0) Ahi Evran Üniversitesi, 275’i (\%12.5) Gazi Üniversitesi, 115'i (\%5.2) Fırat Üniversitesi, 229’u (\%10.4) Erzincan Üniversitesi, 190’ı (\%8.7) Abant İzzet Baysal Üniversitesi, 145'i (\%6.6) Trakya Üniversitesi, 199’u (\%9.1) Pamukkale Üniversitesi, 122'si (\%5.6) Adıyaman Üniversitesindendir.

\section{Veri Toplama Araç ve Teknikleri}

Araştırmanın veri toplama aracı olarak Sosyal Bilgiler öğretmen adaylarının mesleki özyeterlik algılarını belirlemek amacıyla "Öğretmen Özyeterlik Ölçeği" kullanılmıştır. Tschannen-Moran ve Hoy (2001) tarafından geliştirilmiş olan ölçeğin orijinal formu Türkçeye uyarlama, geçerlik ve güvenirlik çalışması Çapa, Çakıroğlu ve Sarıkaya (2005) tarafından yapılmıştır. "Öğretmen Özyeterlik Ölçeği” toplam 24 maddeden ve üç alt boyuttan oluşmaktadır. "Öğrenci katılımına yönelik özyeterlik" boyutu , "Öğretim stratejilerine yönelik özyeterlik" boyutu "Sınıf yönetimine yönelik özyeterlik" boyutu şeklindedir. Bu çalışmada yapılan güvenirlik analizleri sonucunda ölçeğin tamamı için iç tutarlık katsayısı .95 olarak bulunmuştur. Ayrıca her bir boyut için ayrı ayrı hesaplanan iç tutarlılık katsayıları, "Öğrenci katılımına yönelik özyeterlik" için .86, "Öğretim stratejilerine yönelik özyeterlik" için .87, "Sınıf yönetimine yönelik özyeterlik" için .86 olarak bulunmuştur.

\section{Verilerin Toplanması ve Analizi}

Araştırmada katılımcılardan elde edilen veriler SPSS 16.0 istatistik paket programı kullanılarak analiz edilmiştir. Frekans ve yüzde analizleri yapılmıs, aritmatik ortalama ve standart sapma değerleri bulunmuştur. Algılar arasındaki farklılıklar iiçin ise $t$ testi ve tek yönlü varyans analizi kullanılmıştır.

\section{Bulgular}

Araştırmanın bu kısmında Sosyal Bilgiler öğretmen adaylarının mesleki özyeterlik algı düzeylerine ilişkin ortalama ve standart sapma verilerine yer verilmiştir. 
Tablo 1. Sosyal Bilgiler Öğretmen Adaylarının Mesleki Özyeterliklerine ilişkin Algıları Düzeyleri

\begin{tabular}{lcc}
\hline Değişkenler & $\bar{X}$ & $S$ \\
\hline 1. Öğrenci katılımına yönelik özyeterlik & 6.69 & 1.18 \\
2. Öğretim stratejilerine yönelik özyeterlik & 6.75 & 1.21 \\
3. Sınıf yönetimine yönelik özyeterlik & 6.80 & 1.22 \\
4. Öğretmen Özyeterliği (Toplam) & 6.75 & 1.13 \\
\hline
\end{tabular}

Genel olarak Sosyal Bilgiler öğretmen adaylarının özyeterlik algıları incelendiğinde 6.75 düzeyindeki ortalamanın likert tipi ölçeğin "oldukça yeterli" karşılığına denk gelmektedir. Öğretmen adaylarının özyeterlik algılarına üç boyut açısından incelendiğinde "Sınıf yönetimine yönelik özyeterlik" boyutunun en yüksek ( $\bar{X}=6.80$ ); "Öğrenci katılımına yönelik özyeterlik" boyutunun ise en düşük değeri ( $\bar{X}=6.69)$ aldığı bulunmuştur.

\section{Öğretmen Özyeterlik Maddelerine ilişkin ortalama ve standart sapma değerlerine ilişkin Bulgular}

Araştırmanın bu kısmında öğretmen özyeterlik maddelerine ilişkin ortalama ve standart sapma değerlerine ilişkin verilere yer verilmiştir.

Tablo 2. Öğretmen özyeterlik maddelerine ilişkin ortalama ve standart sapma değerleri

\begin{tabular}{|c|c|c|}
\hline Öğretmen Özyeterlik Maddeleri & $\bar{X}$ & $S$ \\
\hline 1. Çalışması zor öğrencilere ulaşmayı ne kadar başarabilirsiniz? & 6.02 & 1.74 \\
\hline 2. Öğrencilerin eleştirel düşünmelerini ne kadar sağlayabilirsiniz? & 6.56 & 1.59 \\
\hline $\begin{array}{l}\text { 3. Sınıfta dersi olumsuz yönde etkileyen davranışları kontrol etmeyi ne kadar } \\
\text { sağlayabilirsiniz? }\end{array}$ & 6.75 & 1.68 \\
\hline 4. Derslere az ilgi gösteren öğrencileri motive etmeyi ne kadar sağlayabilirsiniz? & 6.72 & 1.64 \\
\hline 5. Öğrenci davranışlarıyla ilgili beklentilerinizi ne kadar açık ortaya koyabilirsiniz? & 6.87 & 1.61 \\
\hline 6. Öğrencileri okulda başarılı olabileceklerine inandırmayı ne kadar sağlayabilirsiniz? & 7.03 & 1.63 \\
\hline 7. Öğrencilerin zor sorularına ne kadar iyi cevap verebilirsiniz? & 6.50 & 1.63 \\
\hline 8. Sınıfta yapılan etkinliklerin düzenli yürümesini ne kadar iyi sağlayabilirsiniz? & 6.81 & 1.66 \\
\hline 9. Öğrencilerin öğrenmeye değer vermelerini ne kadar sağlayabilirsiniz? & 6.83 & 1.67 \\
\hline $\begin{array}{l}\text { 10. Öğrettiklerinizin öğrenciler tarafından kavranıp kavranmadığını ne kadar iyi } \\
\text { değerlendirebilirsiniz? }\end{array}$ & 6.84 & 1.60 \\
\hline $\begin{array}{l}\text { 11. Öğrencilerinizi iyi bir şekilde değerlendirmesine olanak sağlayacak soruları ne } \\
\text { ölçüde hazırlayabilirsiniz? }\end{array}$ & 6.86 & 1.60 \\
\hline 12. Öğrencilerin yaratıcılığının gelişmesine ne kadar yardımcı olabilirsiniz? & 6.75 & 1.67 \\
\hline 13. Öğrencilerin sınıf kurallarına uymalarını ne kadar sağlayabilirsiniz? & 7.06 & 1.64 \\
\hline 14. Başarısız bir öğrencinin dersi daha iyi anlamasını ne kadar sağlayabilirsiniz? & 6.68 & 1.63 \\
\hline $\begin{array}{l}\text { 15. Dersi olumsuz yönde etkileyen ya da derste gürültü yapan öğrencileri ne kadar } \\
\text { yatıştırabilirsiniz? }\end{array}$ & 6.84 & 1.67 \\
\hline $\begin{array}{l}\text { 16. Farklı öğrenci gruplarına uygun sınıf yönetim sistemi ne kadar iyi } \\
\text { oluşturabilirsiniz? }\end{array}$ & 6.49 & 1.68 \\
\hline 17. Derslerin her bir öğrencinin seviyesine uygun olmasını ne kadar sağlayabilirsiniz? & 6.50 & 1.69 \\
\hline 18. Farklı değerlendirme yöntemlerini ne kadar kullanabilirsiniz? & 6.68 & 1.70 \\
\hline $\begin{array}{l}\text { 19. Birkaç problemli öğrencinin derse zarar vermesini ne kadar iyi } \\
\text { engelleyebilirsiniz? }\end{array}$ & 6.78 & 1.71 \\
\hline $\begin{array}{l}\text { 20. Öğrencilerin kafası karıştığında ne kadar alternatif açıklama ya da örnek } \\
\text { sağlayabilirsiniz? }\end{array}$ & 6.90 & 1.63 \\
\hline 21. Sizi hiçe sayan davranışlar gösteren öğrencilerle ne kadar iyi baş edebilirsiniz? & 6.82 & 1.86 \\
\hline $\begin{array}{l}\text { 22. Çocuklarının okulda başarılı olmalarına yardımcı olmaları için ailelere ne kadar } \\
\text { destek olabilirsiniz? }\end{array}$ & 6.87 & 1.70 \\
\hline 23. Sınıfta farklı öğretim yöntemlerini ne kadar iyi uygulayabilirsiniz? & 6.81 & 1.69 \\
\hline 24. Çok yetenekli öğrencilere uygun öğrenme ortamını ne kadar sağlayabilirsiniz? & 6.91 & 1.74 \\
\hline
\end{tabular}

Öğretmen özyeterlik maddelerine ilişkin ortalamalar incelendiğinde en yüksek ortalamayı şu maddeler almaktadır: Öğrencilerin sınıf kurallarına uymalarını ne kadar sağlayabilirsiniz? ( $\bar{X}=7.06)$, öğrencileri okulda başarılı olabileceklerine inandırmayı ne kadar sağlayabilirsiniz? ( $\bar{X}=7.03)$, çok yetenekli öğrencilere uygun öğrenme ortamını 
ne kadar sağlayabilirsiniz? ( $\bar{X}=6.91)$, öğrencilerin kafası karıştığında ne kadar alternatif açıklama ya da örnek sağlayabilirsiniz? $(\bar{X}=6.90)$, çocuklarının okulda başarılı olmalarına yardımcı olmaları için ailelere ne kadar destek olabilirsiniz? ( $\bar{X}=6.87)$, öğrenci davranışlarıyla ilgili beklentilerinizi ne kadar açık ortaya koyabilirsiniz? $(\bar{X}=6.87)$.

Ortalamalar incelendiğinde en düşük ortalamayı şu maddeler almaktadır: Çalışması zor öğrencilere ulaşmayı ne kadar başarabilirsiniz? ( $\bar{X}=6.02$ ), farklı öğrenci gruplarına uygun sınıf yönetim sistemi ne kadar iyi oluşturabilirsiniz? $(\bar{X}=6.49)$, öğrencilerin zor sorularına ne kadar iyi cevap verebilirsiniz? $(\bar{X}=6.50)$, derslerin her bir öğrencinin seviyesine uygun olmasını ne kadar sağlayabilirsiniz? $(\bar{X}=6.50)$, öğrencilerin eleştirel düşünmelerini ne kadar sağlayabilirsiniz? $(\bar{X}=6.50)$,

Sosyal Bilgiler Öğretmen Adaylarının Özyeterlik Algılarının Cinsiyet Değişkenine Göre Farklılığı İçin Yapılan TTesti Sonuçlarına İlişkin Bulgular

Sosyal Bilgiler öğretmen adaylarının özyeterlik algılarının cinsiyet değişkenine göre farklılığı için yapılan t-testi sonuçları Tablo 3'de verilmiştir.

Tablo 3. Sosyal Bilgiler öğretmen adaylarının mesleki özyeterlik algılarının cinsiyete göre karşılaştırılmasına yönelik t-testi sonuçları

\begin{tabular}{llccccc}
\hline Cinsiyet & $N$ & $\bar{X}$ & $s$ & $s d$ & $t$ & $p$ \\
\hline Erkek & 991 & 6.72 & 1.16 & 2191 & 1.177 & .239 \\
Kadın & 1202 & 6.78 & 1.10 & & & \\
\hline \multicolumn{2}{c}{$\mathrm{p}>.05$} & & & & &
\end{tabular}

Tablo 3 incelendiğinde, Sosyal Bilgiler öğretmen adaylarının özyeterlik algıları öğretmen adaylarının cinsiyetine göre anlamlı bir farklılık göstermemektedir $\left[t_{(2191)}=1.177, p>.05\right]$. Diğer bir ifadeyle, kadın ve erkek öğretmen adaylarının özyeterlik algılarında bir farklılaşmanın olmaması cinsiyet değişkeninin belirleyici bir etkiye sahip olmadığını göstermektedir.

\section{Sosyal Bilgiler Öğretmen Adaylarının Özyeterlik Algılarının Sınıf Düzeyi Değişkenine Göre Farklılığı İçin Yapılan ANOVA Sonuçları}

Sosyal Bilgiler öğretmen adaylarının özyeterlik algılarının sınıf düzeyi değişkenine göre farklıığı için yapılan tek yönlü varyans analizi (ANOVA) sonuçları Tablo 4.14'de verilmiştir.

Tablo 4. Sosyal Bilgiler öğretmen adaylarının mesleki özyeterlik algılarının sınıf düzeyine göre karşılaştırılmasına yönelik ANOVA sonuçları

\begin{tabular}{rccccccc}
\hline Sınıf Düzeyi & $N$ & $\overline{\mathrm{X}}$ & $s$ & sd & $F$ & $\mathrm{p}$ & Anlam \\
\hline 1. sınıf & 543 & 6.83 & 1.21 & & & \\
2. sınıf & 589 & 6.79 & 1.05 & 3 & & $1-4^{*}$ \\
3. sınıf & 556 & 6.73 & 1.06 & 2189 & 3.805 & .010 & $2-4^{*}$ \\
4. sınıf & 505 & 6.61 & 1.18 & & & \\
Toplam & 2193 & 6.75 & 1.13 & & & \\
\hline
\end{tabular}

$* p<.05$

Tablo 4 incelendiğinde, Sosyal Bilgiler öğretmen adaylarının özyeterlik algılarının sınıf düzeyi değişkenine göre anlamlı farklılık göstermektedir $\left[F_{(3-2189)}=3.805, p<.05\right]$. Diğer bir ifadeyle, Sosyal Bilgiler öğretmen adaylarının özyeterlik algıları sınıf düzeyine göre anlamlı bir şekilde değişmektedir. 
Levene testi sonuçlarına baktığımızda $L_{F}=7.447$ ve $\operatorname{Sig}(p)=.000$ olarak belirlenmiş, $p<.05$ olduğundan dolayı varyans homojen dağılım göstermemektedir. Varyansların homojen dağılım göstermemesinden dolayı Dunnett's $C$ testinden yararlanılmıştır.

Farkların hangi sınıf düzeyleri arasında olduğunu bulmak amacıyla yapılan Dunnett's $C$ testinin sonuçlarına göre Sosyal Bilgiler 1. sınıf öğretmen adaylarının özyeterlik algıları ile Sosyal Bilgiler 4. sınıf öğretmen adaylarının özyeterlik algıları arasında anlamlı farklılık saptanmıştır. Ayrıca Sosyal Bilgiler 2. sınıf öğretmen adaylarının özyeterlik algıları ile Sosyal Bilgiler 4. sınıf öğretmen adaylarının özyeterlik algıları arasında da anlamlı farklılık saptanmıştır. Sosyal Bilgiler 4. sınıf öğretmen adaylarının özyeterlik algıları $(\bar{X}=6.61)$, Sosyal Bilgiler 1. sınıf öğretmen adaylarının özyeterlik algılarından $(\bar{X}=6.83)$, Sosyal Bilgiler 2. sınıf öğretmen adaylarının özyeterlik algılarından $(\bar{X}=6.79)$, düşüktür. Sosyal Bilgiler öğretmen adaylarının özyeterlik algıları 1. sınıfta en yüksek düzeyde; 4. sınıfta ise en düşük düzeydedir.

\section{Sosyal Bilgiler Öğretmen Adaylarının Özyeterlik Algılarının Üniversite Değişkenine Göre Farklılığı İçin Yapılan ANOVA Sonuçları}

Sosyal Bilgiler öğretmen adaylarının özyeterlik algılarının üniversite değişkenine göre farklılığı için yapılan tek yönlü varyans analizi (ANOVA) sonuçları Tablo 4.15 'de verilmiştir.

Tablo 5. Sosyal Bilgiler öğretmen adaylarının mesleki özyeterlik algılarının üniversitelere göre karşılaştırılmasına yönelik anova sonuçları

\begin{tabular}{|c|c|c|c|c|c|c|c|}
\hline Üniversite & $N$ & $\bar{X}$ & $s$ & $d$ & $F$ & $p$ & Anlam \\
\hline 1. Kastamonu & 215 & 6.88 & 1.10 & & & & $1-8^{*}$ \\
\hline 2. Karadeniz Teknik & 189 & 6.75 & 1.02 & & & & $3-8^{*}$ \\
\hline 3. Mehmet Akif Ersoy & 167 & 6.85 & 1.06 & & & & $4-8^{*}$ \\
\hline 4. Marmara & 128 & 6.91 & .95 & & & & $5-7^{*}$ \\
\hline 5. Ahi Evran & 219 & 6.93 & 1.04 & 11 & & & $5-8^{*}$ \\
\hline 6. Gazi & 275 & 6.69 & 1.25 & 2181 & 5.172 & & $6-10^{*}$ \\
\hline 7. Firat & 115 & 6.44 & 1.28 & & & .000 & $7-10^{*}$ \\
\hline 8. Erzincan & 229 & 6.43 & 1.26 & & & & $8-10^{*}$ \\
\hline 9. Abant İzzet Baysal & 190 & 6.64 & 1.20 & & & & $9-10^{*}$ \\
\hline 10. Trakya & 145 & 7.08 & .87 & & & & $10-11^{*}$ \\
\hline 11. Pamukkale & 199 & 6.67 & 1.02 & & & & \\
\hline 12. Adıyaman & 122 & 6.82 & 1.16 & & & & \\
\hline Toplam & 2193 & 6.75 & 1.13 & & & & \\
\hline
\end{tabular}

Tablo 5 incelendiğinde, Sosyal Bilgiler öğretmen adaylarının özyeterlik algılarının üniversite değişkenine göre anlamlı farklılık göstermektedir $\left[F_{(11-2181)}=5.172, p<.05\right]$. Diğer bir ifadeyle, Sosyal Bilgiler öğretmen adaylarının özyeterlik algıları üniversitelere göre anlamlı bir şekilde değişmektedir.

Levene testi sonuçlarına baktığımızda $L F=5.282$ ve $\operatorname{Sig}(p)=.000$ olarak belirlenmiş, $p<.05$ olduğundan dolayı varyans homojen dağılım göstermemektedir. Varyansların homojen dağılım göstermemesinden dolayı Dunnett's $C$ testinden yararlanılmıştır.

Farkların hangi üniversiteler arasında olduğunu belirlemek için yapılan Dunnett's $C$ testinin verilerine göre Erzincan Üniversitesinde öğrenim gören öğretmen adaylarının özyeterlik algıları ile Kastamonu, Karadeniz Teknik, Mehmet Akif Ersoy ve Ahi Evran Üniversitesinde öğrenim gören öğretmen adaylarının özyeterlik algıları arasında anlamlı farklılık bulunmuştur. Ahi Evran Üniversitesinde öğrenim gören öğretmen adaylarının özyeterlik algıları ile Fırat Üniversitesinde öğrenim gören öğretmen adaylarının özyeterlik algıları arasında anlamlı farklılık bulunmuştur. Trakya Üniversitesinde öğrenim gören öğretmen adaylarının özyeterlik algıları ile Gazi, Fırat, Erzincan, Abant İzzet Baysal Üniversitesinde öğrenim gören öğretmen adaylarının özyeterlik algıları arasında anlamlı farklılık bulunmuştur. Ayrıca, Trakya Üniversitesinde öğrenim gören öğretmen adaylarının özyeterlik algıları ile Pamukkale Üniversitesinde öğrenim gören öğretmen adaylarının özyeterlik algıları arasında anlamlı farklılık bulunmuştur. Trakya Üniversitesinde öğrenim gören öğretmen adaylarının özyeterlik algılarının en yüksek düzeyde; Erzincan Üniversitesinde öğrenim gören öğretmen adaylarının özyeterlik algılarının en düşük düzeyde olduğu görülmektedir. 


\section{Tartışma ve Sonuç}

Genel olarak Sosyal Bilgiler öğretmen adaylarının özyeterlik algılarına bakıldığında "oldukça yeterli" düzeyde olduğu saptanmıştır. Araştırma bulguları (Mutlu Bozkurt, 2013; Kan, 2007; Yeşilyurt, 2013; Gerçek, Yılmaz, Köseoğlu ve Soran, 2006; Harurluoğlu ve Kaya, 2009; Yılmaz ve Gürçay, 2011) tarafından yapılan çalışmaların bulgularıyla benzerlik göstermektedir. Sosyal Bilgiler öğretmen adaylarının özyeterlik algılarına üç boyut kapsamında incelendiğinde "Sınıf yönetimine yönelik özyeterlik" boyutunun en yüksek; "Öğrenci katılımına yönelik özyeterlik" boyutunun ise en düşük değeri aldığı saptanmıştır. Ayra ve Kösterelioğlu (2016) yaptığı araştırma bulgularında da "öğrenci katılımına yönelik özyeterlik" boyutunda öğretmenlerin, öğrencileri derse dahil etme, motivasyonlarını sağlama ve başaracakları algısını güçlendirme gibi konularda başka alanlara göre kendilerini daha az yeterli gördükleri belirlenmiştir. Bununla birlikte, araştırmamızın bulgularına göre üç boyut için öğretmen adaylarının özyeterlik algıları "oldukça yeterli" düzeyinde olmuştur. Recepoğlu ve Ergün (2017) tarafından yapılan çalışmada, Sosyal Bilgiler öğretmen adaylarının sınıfı yönetebilme becerisi hususunda kendilerini yeterli olarak algıladıkları belirlenmiştir.

Öğretmen özyeterlik maddelerine ilişkin ortalamalar incelendiğinde en yüksek ortalamayı: Öğrencilerin sınıf kurallarına uymalarını sağlayabilme, öğrencileri okulda başarılı olabileceklerine inandırabilme, çok yetenekli öğrencilere uygun öğrenme ortamını sağlayabilme, öğrencilerin kafası karıştığında ayrıntılı açıklama veya örnek verebilme, çocuklarının okuldaki başarısı için aile desteği verebilme, öğrenci davranışlarıyla ilgili beklentilerini açık ortaya koyabilme gibi konularda öğretmenlerin özyeterlik algılarının yüksek olduğu belirlenmiştir. Sosyal bilgiler öğretmen adaylarının sınıf yönetimi ve öğretim stratejilerine yönelik özyeterlik algılarının yüksek olması akademik performanslarında olumlu etkisi olabileceği düşünülebilir.

Ortalamalar incelendiğinde en düşük ortalamayı: Çalışması zor öğrencilere ulaşmayı başarabilme, farklı öğrenci gruplarına uygun sınıf yönetim sistemi oluşturabilme, zor sorulara cevap verebilme, derslerin her bir öğrencinin seviyesine uygun olmasını sağlayabilme, öğrencilerin eleştirel düşünmelerini sağlayabilme gibi konularda öğretmenlerin özyeterlik ağılarının düşük olduğu belirlenmiştir. Araştırmanın bu bulgusuna göre, sosyal bilgiler öğretmen adaylarının, öğrenci katılımını sağlamayı ne düzeyde başarabilecekleri ile ilgili kendilerini yetersiz hissettikleri söylenebilir. Sosyal bilgiler öğretmen adaylarının, öğrenci katılımını sağlama konusunda kendilerini yetersiz hissetmeleri öğretmenlik mesleğine yönelik performans ve motivasyonlarında olumsuz etkisi olabileceği söylenebilir.

Sosyal Bilgiler öğretmen adaylarının özyeterlik algıları öğretmen adaylarının cinsiyetine göre anlamlı bir farklılık göstermemektedir. Araştırmanın bulguları, Akkuzu ve Akçay, 2012; Akbaş ve Çelikkaleli, 2006; Akbulut, 2006; Altunçekiç, Yaman ve Koray,2005; Ekinci, Yıldııım, Bindak, Öter, Özdaş ve Akın, 2014; Çakıroğlu, Çakıroğlu ve Boone, 2005; Demirtaş, Cömert ve Özer, 2009; Ekici, 2008; Can, Günhan ve Erdal, 2005; Coşgun ve illgar, 2004; Çoban ve Sanalan, 2002; Gerçek, Yılmaz, Köseoğlu ve Soran, 2006; Güven ve Ersin, 2007; Karadeniz ve Özdemir, 2006; Küçükyılmaz ve Duban, 2006; Yüksel, 2014; Zayimoğlu-Öztürk, 2013) tarafından yapılan çalışmaların bulgularıyla benzerlik göstermektedir.

Sosyal Bilgiler öğretmen adaylarının özyeterlik algılarının sınıf düzeyi değişkenine göre anlamlı farklıık göstermektedir. Farkların hangi sınıf düzeyleri arasında olduğuna bakıldığında, sosyal bilgiler 1. sınıf öğretmen adaylarının özyeterlik algıları ile Sosyal Bilgiler 4. sınıf öğretmen adaylarının özyeterlik algıları arasında anlamlı farklılık saptanmıştır. Araştırmanın bu bulgusu, Sosyal Bilgiler öğretmen adaylarının özyeterlik algılarının sınıf düzeyine göre istatistiksel olarak anlamlı farklılık olduğu sonucu, alan yazında yer alan Yaman ve Koray. (2004); Akbulut (2006); Mutlu Bozkurt (2013),Vural ve Hamurcu (2008); Dönmez ve Uslu (2014), Taşkın ve Hacıömeroğlu (2010)' nun araştırma bulgularıyla paralellik göstermekteyken, Akkuş (2013), Ekinci (2013), Akkuzu ve Akçay (2012), Gerçek, Yılmaz, Köseoğlu ve Soran (2006), Kahyaoğlu ve Yangın (2007)'ın araştırma bulgularıyla ise örtüşmemektedir. Sosyal Bilgiler öğretmen adaylarının özyeterlik algıları 1. sınıfta en yüksek düzeyde; 4. sınıfta ise en düşük düzeydedir. Sınıf düzeyi yükseldikçe Sosyal Bilgiler öğretmen adaylarının özyeterlik algıları düşmektedir. Bu durum özyeterlik inancını en çok etkileyen faktörlerden doğrudan deneyimlerle ilişkilendirilebilir. Bazı araştırma bulgularına göre, uygulama dersleri kapsamında öğretmenlik deneyimi sırasında öğretmen adaylarının özyeterliklerinin azaldığı ve kendilerini yetersiz hissettikleri sonucuna ulaşılmıştır (Talvitie, Peltokallio ve Mannisto, 2000). Öğretmen adaylarının eğitim sürecinin son sınıfında karşılaştıkları Kamu Personel Seçme Sınavı (KPSS) öğretmenlik endişelerini yükseltmekte ve okula olan ilgilerini düşürmektedir. Bundan dolayı öğretmen adaylarının mesleki özyeterliğine etkisi olabilecek doğrudan deneyimleri yaşama imkanına sahip oldukları son sınıftaki okul deneyimi ve öğretmenlik uygulaması gibi dersler verimli geçmemekte ve öğretmen adaylarının mesleki özyeterliğini negatif yönde etkilemektedir. 
Sosyal Bilgiler öğretmen adaylarının özyeterlik algılarının üniversite değişkenine göre anlamlı farklılık göstermektedir. Araştırmanın bulgularına göre, üniversite değişkenin Sosyal Bilgiler öğretmen adaylarının özyeterlik algılarına etki ettiği söylenebilir. Araştırmada elde edilen bu sonuç, Zayimoğlu Öztürk (2011)'ün Sosyal Bilgiler öğretmenlerinin ve öğretmen adaylarının ilköğretim Sosyal Bilgiler dersi öğretim programında yer alan öğrenme alanlarına iliş̧in özyeterlik düzeylerinin incelenmesi üzerine yaptığı araştırma sonuçlarıyla benzerlik göstermektedir. Uslu (2014) yaptığı çalışmada Sosyal Bilgiler öğretmen adaylarının "Sosyal Bilgiler öğretmeni özel alan yeterliklerine ilişkin özyeterlik inançları" üniversitelerine göre anlamlı bir farklılık saptanmıştır. Şahin (2013)'nin çalışmasında Sosyal bilgiler öğretmen adaylarını "Değerler eğitimi özyeterlilik" puanlarının öğrenim gördükleri üniversiteye göre anlamlı bir farklıık olduğu belirlenmiştir. Aynı zamanda araştırma bulguları, Karademir(2012), Akengin ve arkadaşları (2010), Dönmez ve Uslu (2014), Akkuş (2013)'un araştırma bulgularıyla benzerlik göstermektedir. Diğer taraftan, Kaya (2008)'nın çalışmasında Sosyal Bilgiler öğretmen adaylarının düşünme becerilerinin öğretimine yönelik özyeterlik düzeylerinde öğrenim gördükleri üniversiteye göre farklılık bulunamamıştır. Bu bulgulara göre üniversiteler arasında görülen bu farklılıkların nedenleri olarak farklı eğitimsel uygulamalar, sınıf mevcutları ve ölçme aracının uygulanması sırasında kontrol edilemeyen bazı değişkenlerin etkili olduğu düşünülmektedir. Ayrıca bu durum, farklı üniversitelere yerleşen Sosyal Bilgiler öğretmen adaylarının mevcut durumdaki akademik başarı ve öğrenci profillerine, fiziki altyapı, okul içi ve okul dışı uygulamalar göre değişiklik gösterebileceği şeklinde yorumlanabilir.

\section{Kaynakça}

Akkoyunlu, B. \& Kurbanoğlu, S. (2003). Öğretmen adaylarının bilgi okuryazarlığı ve bilgisayar öz-yeterlik algıları. Hacettepe Üniversitesi Eğitim Fakültesi Dergisi, 24, 1-10.

Akkoyunlu, B., Orhan, F. \& Umay, A. (2005). Bilgisayar öğretmenleri için bilgisayar öğretmenliği özyeterlik ölçeği geliştirme çalışması. Hacettepe Üniversitesi Eğitim Fakültesi Dergisi, 29, 1-8.

Akbaş, A. \& Çelikkaleli, Ö. (2006). Sını öğretmeni adaylarının fen öğretimi özyeterlik inançlarının cinsiyet, öğrenim türü ve üniversitelerine göre incelenmesi. Mersin Üniversitesi Eğitim Fakültesi Dergisi, 2(1), 98-110.

Akbulut, E. (2006). Müzik öğretmeni adaylarının mesleklerine ilişkin özyeterlik inançları. Yüzüncü Yıl Üniversitesi Eğitim Fakültesi Dergisi, 3(2), 24-33.

Akengin, H.; Şahin, C. T.; Kaya, B.; Bengiç, G. \& Sargın, S. (2010). Sosyal bilgiler öğretmen adaylarının bazı genel coğrafya konuları ve bunların öğretimi ile ilgili öz-yeterlik algıları. Marmara Coğrafya Dergisi, 21, 78 - 97.

Akkuş, Z. (2013). Sosyal bilgiler öğretmen adaylarının özyeterlik inanç düzeylerini belirlenmesi üzerine bir çalışma. Dicle Üniversitesi Ziya Gökalp Eğitim Fakültesi Dergisi, 20, 102-116.

Akkuzu, N., \& Akçay, H. (2012). Kimya öğretmen adaylarının öz yeterlik inançlarının farklı değiş̧kenler açısından incelenmesi (Dokuz Eylül Üniversitesi örneği). Educational Sciences: Theory and Practice, 12(3), 2195-2216.

Allinder, R.M. (1994). The relationship between efficacy and the instructional practices of special education teachers and consultants. Teacher Education and Special Education, 17, 86-95.

Altunçekiç, A., Yaman, S. \& Koray, Ö. (2005). Öğretmen adaylarının özyeterlik inanç düzeyleri ve problem çözme becerileri üzerine bir araştırma (Kastamonu ili örneği). Kastamonu Eğitim Dergisi, 13(1), 93-102.

Ashton, P. (1984). Teacher efficacy: A motivational paradigm for effective teacher education. Journal of Teacher Education, 35(5), 28-32.

Aşkar, P. \& Umay, A. (2001). İlköğretim matematik öğretmenliği öğretmen adaylarının bilgisayarla ilgili öz-yeterlik inancı. Hacettepe Üniversitesi Eğitim Fakültesi Dergisi, 21, 1-8.

Ayra, M. \& Kösterelioğlu, í. (2016). Öğretmenlerin mesleki özyeterlik inançlarının çeşitli değiş̧kenler açısından incelenmesi. Gümüshane Üniversitesi Sosyal Bilimler Elektronik Dergisi, 7(17).

Bandura, A. (1986). Social foundations of thought and action: A social cognitive theory. Englewood Cliffs, NJ: Prentice-Hall.

Bandura, A. (1977). Self-efficacy: toward a unifying theory of behavioral change. Psychological Review, 84(2), 191215. 
Bandura, A. (1997). Self-efficacy: The exercise of control. New York: Freeman

Can, B. T., Günhan, B. \& Erdal, S.(2005). Fen bilgisi öğretmen adaylarının fen derslerinde matematiğin kullanımına yönelik öz yeterlik inançlarının incelenmesi. Dokuz Eylül Üniversitesi Buca Eğitim Fakültesi Dergisi, 18, 38-46.

Cannon, J. R., \& Scharmann, L. C. (1996). Influence of a cooperative early field experience on preservice elementary teachers' science self- efficacy. Science Education, 80, 419-436.

Caprara, G. V., Barbaranelli, C., Steca, P., \& Malone, P. S. (2006). Teachers' self-efficacy beliefs as determinants of job satisfaction and students' academic achievement: A study at the school level. Journal of School Psychology, $44,473-490$.

Celep, C. (2000). The correlation of the factors: The prospective teacher' sence of efficacy, beliefs and attitudes about student control. National Forum of Educational Administration and Supervision Journal, 4, 99-112.

Çakıroglu, E., \& Boone, W. J. (2005). Pre-service teacher self-efficacy beliefs regarding science teaching: a comparison of pre-service teachers in Turkey and the USA. Science Educator, 14(1), 31-40.

Çapa, Y., Çakıroğlu, J., \& Sarıkaya, H. (2005). The development and validation of a Turkish version of teachers' sense of efficacy scale. Eğitim ve Bilim (Education and Science),30(137), 74-81.

Çapri, B. \& Çelikkaleli, Ö. (2008). Öğretmen adaylarının öğretmenliğe ilişkin tutum ve mesleki yeterlik inançlarının cinsiyet, program ve fakültelerine göre incelenmesi. İnönü Üniversitesi Eğitim Fakültesi Dergisi, 9(15), 33-53.

Çoban, T. A. \& Sanalan, V. A. Sanalan (2002). Fen bilgisi öğretimi dersinde özgün deney tasarım sürecinin öğretmen adayının özyeterlilik algısına etkisi. Erzincan Eğitim Fakültesi Dergisi, 4(2), 1-10.

Coşgun, S. \& Ilgar, Z.(2004). Rehberlik ve psikolojik danışmanlık deneyimi çalışmalarının adayların öz yeterlilik algılarına etkisi. XIII. Ulusal Eğitim Bilimleri Kurultayı, İnönü Üniversitesi, Eğitim Fakültesi, Malatya: 6-9 Temmuz.

Demirtaş, H., Cömert, M., \& Özer, N. (2011). Öğretmen adaylarının özyeterlik inançları ve öğretmenlik mesleğine ilişkin tutumları. Education and Science, 36, 96-111.

Dönmez, C. ve Uslu, S. (2015). Sosyal bilgiler öğretmen adaylarının özel alan yeterliklerine ilişkin özyeterlik inançlarının çeşitli değiş̧enler açısından incelenmesi. Abant İzzet Baysal Üniversitesi Eğitim Fakültesi Dergisi 14(1), 461-482

Ekici, G. (2008). Sınıf yönetimi dersinin öğretmen adaylarının öğretmen özyeterlik algı düzeyine etkisi. Hacettepe Üniversitesi Eğitim Fakültesi Dergisi, 35, 98-110.

Ekinci, H. (2013). Öğretmen adaylarının özyeterlik algıları: Müzik, resim ve beden eğitimi. International Periodical For The Languages, Literature and History of Turkish or Turkic, 8(3), 189-196.

Ekinci A., Yıldııım M. C., Bindak R., Öter Ö.M., Özdaş F., Akın M. A. (2014). öğretmen adaylarının öğretmenlik mesleğine ilişkin özyeterlik algılarının çeşitli değişkenler açısından incelenmesi ınvestigating candidate teachers' self-efficacy perceptions in terms of different variables, Gaziantep University Journal of Social Sciences 13(3), 723-734.

Enochs, L. G., \& Riggs, I. M. (1990). Further development of an elementary science teaching efficacy belief Instrument: A preservice elementary scale. School Science and Mathematics, 90(8), 694-706.

Gerçek, C., Yılmaz, M., Köseoğlu, P. \& Soran, H. (2006). Biyoloji eğitimi öğretmen adaylarının öğretiminde öz-yeterlik inançları. Ankara Üniversitesi Eğitim Bilimleri Fakültesi Dergisi, 39(1), 57-73.

Gibson, S., \& Dembo, M. (1984). Teacher efficacy: A construct validation. Journal of Educational Psychology, 76(4), 569-582.

Goddard, R. D., Hoy, W. K., \& Hoy, A. W. (2000). Collective teacher efficacy : Its meaning, measure, and ımpact on student Achievement. American Educational Research Journal, 37(2), 479-507.

Guskey, T. R., \& Passaro, P.D. (1994). Teacher efficacy: A study construct dimensions. American Educational Research Journal, 31, 627-643.

Güven, B. \& Ersin, E.(2007). Sınıf öğretmeni adaylarının Hayat Bilgisi ve Sosyal Bilgiler Öğretimi I dersine ilişkin öz yeterlik algıları ve bilişsel tutumlarının belirlenmesi. Pamukkale Üniversitesi Eğitim Fakültesi Dergisi, 21, 15-32. 
Harurluoğlu, Y., \& Kaya, E. (2009). Biyoloji öğretmen adaylarının biyoloji öğretimine yönelik öz-yeterlik inançları, Uludağ Ünv. Eğitim Fakültesi Dergisi, XXII(2), 481-496

Kahyaoğlu, M. \& Yangın, S. (2007). İlköğretim öğretmen adaylarının mesleki özyeterliklerine ilişkin görüşleri. Kastamonu Eğitim Dergisi, 15(1), 73-84.

Kan, A. (2007). Öğretmen adaylarının eğitme-öğretme özyetkinliğine yönelik ölçek geliştirme ve eğitme-öğretme özyetkinlikleri açısından değerlendirilmesi (Mersin Üniversitesi Örneği). Mersin Üniversitesi Eğitim Fakültesi Dergisi, 3(1), 35-50.

Kaptan, S. (1999). Bilimsel araştırma teknikleri. Ankara: Gazi Yayınları.

Karademir, T. (2012). Öğretmenlerin öğrenme nesnesi öz-yeterlilik algılarının farklı değişkenler açısından incelenmesi. Yüksek Lisans Tezi, Ankara Üniversitesi, Ankara

Karadeniz, B. C. \& Özdemir, N. (2006). Sosyal bilgiler öğretmen adaylarının coğrafya öğretiminde özyeterlik algıları. On Dokuz Mayıs Üniversitesi Eğitim Fakültesi Dergisi, 22, 22-30.

Karasar, N. (2006). Bilimsel araştırma yöntemi. Ankara: Nobel Yayın Dağıtım

Kaya, B. (2008). Sosyal bilgiler öğretmen adaylarının düşünme becerilerinin öğretimine yönelik öz-yeterliklerinin değerlendirilmesi. Doktora Tezi, Gazi Üniversitesi Eğitim Bilimleri Enstitüsü, Ankara.

Kurbanoğlu, S. \& Akkoyunlu, B. (2002). Öğretmen adaylarına uygulanan bilgi okuryazarlığı programının etkililiği ve bilgi okuryazarlığı becerileri ile bilgisayar özyeterlik algısı arasındaki ilişki. Hacettepe Üniversitesi Eğitim Fakültesi Dergisi, 22, 98-105

Küçükyılmaz, E. A. \& Duban, N. (2006). Sınıf öğretmeni adaylarının fen öğretimi özyeterlik inançlarının artırılabilmesi için alınacak önlemlere ilişkin görüşleri. Yüzüncü Yıl Üniversitesi Eğitim Fakültesi Dergisi, 3(2), 1-23

Milner, H. R., \& Woolfolk Hoy, A. (2002). Respect, social support, and teacher efficacy: a case study. Paper presented at the annual meeting of the American Educational Research Association, Session 26.65: Knowledge of self in the development of teacher expertise. April 3, New Orleans, LA.

Moore, W. \& Esselman, M. (1992). Teacher efficacy, power, school climate and achievement: A desegregating district's experience. Paper presented at the annual meeting of the American Educational Research Association, San Francisco.

Morgil, ì., Seçken, N. \& Yücel, A. S. (2004). Kimya öğretmen adaylarının öz-yeterlik inançlarının bazı değişkenler açısından incelenmesi. Balıkesir Üniversitesi Fen Bilimleri Enstitüsü Dergisi, 6(1), 62-72.

Mutlu Bozkurt, T. (2013).Beden eğitimi öğretmen adaylarının öğretmenlik özyeterliklerinin incelenmesi. Yüksek Lisans Tezi, Gazi Üniversitesi, Eğitim Bilimleri Enstitüsü, Ankara.

Özdemir, S. M. (2008). Sınıf öğretmeni adaylarının öğretim surecine ilişkin özyeterlik inançlarının çeşitli değişkenler acısından incelenmesi. Kuram ve Uygulamada Eğitim Yönetimi, 54, 277-306.

Özenoğlu Kiremit, H. (2006). Fen bilgisi öğretmenliği öğrencilerinin biyoloji ile ilgili öz-yeterlik inançlarının karşılaştırılması. Yayınlanmamış doktora tezi, Dokuz Eylül Üniversitesi, İzmir.

Recepoğlu, S, \& Ergün, M. (2017). Sosyal bilgiler öğretmen adaylarının sınıfı yönetebilme becerilerine ilişkin algıları. Kastamonu Üniversitesi Kastamonu Eğitim Dergisi, 25 (4), 1337-1352.

Savran, A. \& Çakıroğlu, J. (2001). Biyoloji öğretmen adaylarının biyoloji öğretimine ilişkin özyeterlilik inançları. Hacettepe Üniversitesi Eğitim Fakültesi Dergisi, 21, 105-112.

Soodak, L. C., \& Podell, D. M. (1998). Teacher efficacy and the vulnerability of the difficult-to-teach student. Advances in Research on Teaching, 7, 75-109.

Şahin T. (2013). Sosyal bilgiler öğretmen adaylarının değerler eğitimi özyeterliliklerinin incelenmesi. Yayınlanmamış yüksek lisans tezi. Marmara Üniversitesi Eğitim Bilimleri Enstitüsü, İstanbul.

Talvitie, U., Peltokallio, L., \& Mannisto, P. (2000). Student teachers' views about their relationships with university supervisors, cooperating teachers and peer student teachers. Scandinavian Journal of Educational Research, 44(1), 79-88. 
Taşkın, Ç. Ş. ve Hacıömeroğlu, G. (2010). Öğretmen özyeterlik inanç ölçeğinin türkçeye uyarlanması ve sınıf öğretmeni adaylarının özyeterlik inançları. Dokuz Eylül Üniversitesi Buca Eğitim Fakültesi Dergisi, 27, 63-75.

Tatlı Dalioğlu, S. (2016). Öğretmen adaylarının meslekteki ilk yıllarına yönelik olası benlikleri ile öz-yeterlik inançları ve öğretmenliğe ilişkin tutumları arasındaki ilişki. Yayınlanmamış doktora tezi. Anadolu Üniversitesi Eğitim Bilimleri Enstitüsü, Eskişehir

Tschannen-Moran, M. \& Woolfolk Hoy, A. (2001). Teacher efficacy: capturing an elusive construct. Teaching and Teacher Education, 17, 783-805.

Tschannen-Moran, M., \& Hoy, A. W. (2007). The differential antecedents of self-efficacy beliefs of novice and experienced teachers. Teaching and Teacher Education, 23(6), 944-956.

Tschannen-Moran, M., Woolfolk-Hoy, A. \& Hoy, W. K. (1998). Teacher efficacy: Its meaning and measure. Review of Educational Research, 68(2), 202-248.

Uslu, S. (2014). Sosyal bilgiler öğretmen adaylarının özel alan yeterliliğine ilişkin öz-yeterlik inançlarının incelenmesi. Doktora tezi, Gazi Üniversitesi, Eğitim Bilimleri Enstitüsü, Ankara

Usluel, Y. K. (2006). Öğretmen adayları ve öğretmenlerin bilgi okuryazarlığı özyeterliklerinin karşılaştırılması. Eğitim Araştırmaları, 6(22), 233-243.

Viau, R. (2015). Okulda motivasyon. Okulda güdülenme ve güdülenmeyi öğrenme. (Çev. Y. Budak). Ankara. Anı yayıncilı.

Vural, D.E. \& Hamurcu, H. (2008). Okul Öncesi Öğretmen Adaylarının Fen Öğretimi Dersine Yönelik Öz-yeterlik İnançları ve Görüşleri, Elementary Education Online, 7(2),

Woolfolk, A. E., \& Hoy, W. K. (1990). Prospective teachers' sense of efficacy and beliefs about control. Journal of Educational Psychology, 82: 81-91.

Yaman, S., Koray, Ö. C. \& Altunçekiç, A. (2004). Fen bilgisi öğretmen adaylarının öz yeterlik inanç düzeylerinin incelenmesi üzerine bir araştırma. Türk Eğitim Bilimleri Dergisi, 2(3) 355-364.

Yeşilyurt, E. (2013). Öğretmen adaylarının öğretmen özyeterlđk algıları. Elektronik Sosyal Bilimler Dergisi, 12(45), 88104.

Yılmaz, M., \& Gürçay, D. (2011). Biyoloji ve fizik öğretmen adaylarının öğretmen özyeterliklerini yordayan değişkenlerin belirlenmesi, Çukurova Ünv. Eğitim Fakültesi Dergisi, 1(40), 53-6

Yüksel, I. (2014). Investigation the impact of classroom management course self efficacy levels: An experimental study on pre-service teachers. Education and Science, 39(171), 259-26.

Zayimoğlu Öztürk, F. (2011). Sosyal Bilgiler öğretmenlerinin ve öğretmen adaylarının ilköğretim sosyal bilgiler dersi öğretim programında yer alan öğrenme alanlarına ilişkin özyeterlik düzeylerinin incelenmesi Yayımlanmamış doktora tezi. Gazi Üniversitesi Eğitim Bilimleri Enstitüsü, Ankara

Zayimoğlu-Öztürk, F. (2013). Sosyal Bilgiler öğretmen adaylarının sosyal bilgiler öğretim programındaki öğrenme alanlarına ilişkin özyeterlik düzeylerinin ġncelenmesi. Gaziantep University Journal of Social Sciences - JSS, 12 (3), 545-565. 